\title{
Factors Influencing Consumers' Behavioural Intentions Towards Restaurant Patronage in China: A Structural Equation Modeling Approach
}

\author{
Mustafa Rashid Makassy* Qingfeng Meng \\ School of Management, Jiangsu University, Zhenjiang 212013, China
}

\begin{abstract}
We investigated the effect of service quality on customers satisfaction as well as assessed the effects of restaurant image and customer satisfaction on behevioural intention of restaurant patrons in China. Data for the study was obtained from 329 sample restaurant patrons in the Jiangsu Province of china using structured questionnaires. The data for the study was analysed by the help of SPSS and SmartPLS software for the structural equation modeling analysis. Findings from this study found a direct and positive relationship between service quality and customer satisfaction, perceived value and restaurant image. Also, service quality had an indirect effect on customer satisfaction through perceived value and restaurant image. Additionally, the findings of this study revealed that, service quality, customer satisfaction and brand or restaurant image all have a positive impact on the behavioural intention of restaurant patrons. The study concludes that patronage or re-patronage intention of restaurant customers depends largely on the quality of service, customer satisfaction and restaurant image. As such, firms that need to carve niche for themselves in the hospitality industry must focus on building a strong and positive brand image that resonates with customers. The study proffered some recommendations for management of restaurants.
\end{abstract}

Keywords: Service quality; Customer satisfaction; Restaurant image; Behavioural intention; Restaurant; China DOI: $10.7176 / \mathrm{JMCR} / 66-05$

Publication date:March $31^{\text {st }} 2020$

\section{Introduction}

A look at the Chinese restaurant sector indicates proliferation of restaurants in cities, towns and regions all across china. This proliferation might be connected to the overall rise in general economic and social wellbeing of the people. China has been on the rise economically for over two decades now and the economic outlook of the country looks phenomenon. This has resulted in the creation of economic freedom and the citizens seem to be living lavish life styles. There is an upsurge in the patronage of restaurants services for the Chinese as they prefer to eat out especially the working class. The increase patronage of restaurant services in every developing city of the world might be influenced by globalization (Tabassum \& Rahman, 2012). According to Ahmed, Hossain, Malek, and Begum (2008), there is an increase in the trend of restaurant patronage in the upper class in society, especially among teenagers and the youth. Also, Park (2004) explained the reasons for eating out at fast food restaurants includes satisfying hunger, convenience, pleasure, entertainment, time saving, social interaction and the mood transformation (Olise, Okoli, \& Ekeke, 2015)

Most customers are accustomed to the European or American type of restaurant that provides fast food option for customers. Notable among these fast food restaurants include the Kentucky Fried Chicken (KFC)c, McDonalds, Pizza Hut, Subway, Marry Brown, and so on. Coincidentally, a number of these fast food restaurants are also available in most Chinese cities and towns. However, there are other competing Chinese brands that offer similar menus to customers across the different customer segments. Majority of these restaurants provide various Chinese cuisine and targeted at both natives and foreigners alike.

According to the data from the McKinsey Global Institute analysis, by the year 2025, the urban households of China will make up one of the largest consumer markets in the world, spending about 20 trillion yuan per year (Farrell, Gersch, \& Stephenson, 2006). Economic growth and development in China can be clearly influenced by the expanding of the middle class and increase in their purchasing power is an attraction to both local and international companies. This study targets the middle class in china to determine factors that influence their choice and patronage of restaurants services. The reasons for targeting middle-class consumers include the fact that middle class spending growth has been primarily driven by consumers in the upper-middle income band, which have a significant amount of disposable income.

A review of the extant literature shows that reasons customers patronize restaurants include "food quality, service quality, environment, price, and quick service" (Akbar \& Alaudeen, 2012; Tabassum \& Rahman, 2012; Tat, Sook-Min, Ai-Chin, Rasli, \& Hamid, 2011), "restaurant image" (Ling, Mun, \& Ling, 2011) "and fast food store image factors, customers' values of eating-out, customers' opinions about the globalization" (Ibrahim \& Vignali, 2005).

The research on the customer loyalty in China has gained much attention in the popular press but there is a 
scarcity in the research literature and its scope is very limited. The research on the pivotal determinants of consumers' shopping behavior and choice of products to consume, such as the perceived value, quality and price, has provide few conclusive findings (Parasuraman, Zeithaml, \& Berry, 1988). The effects of quality, value and customer satisfaction have been examined by (Brady, Cronin, \& Brand, 2002). These researchers claim that, available literature on the above shows conflicting research findings and the importance of these constructs are yet to be investigated. This gap in the literature has brought about the need for research, regarding the effects of service quality, value and consumer satisfaction on the purchase intentions of the consumers as well as the customer loyalty to particular service environment.

Additionally, the service literature has been dominated by the study of service value, service quality and consumer satisfaction. There is both, operative and conceptual focus on the discussion, with the intention to identify the relationships between these concepts. Customer satisfaction and service quality have been studied in great length due to their overlapping effects and interrelationships, and the integration of the factors to reflect the consumer loyalty under several cultural backgrounds. This study thus, aims at assessing the effect of service quality on customer satisfaction as well as the effect of customer satisfaction on the patronage behavior of restaurant customers in China.

Accordingly, the following specific objectives are explored;

- Assess the effect of perceived service quality on customer satisfaction, restaurant image and perceived value

- Examine the effect of customer satisfaction and restaurant image on behavioural intention of customers.

\section{Literature review}

\subsection{Perceived Service quality and customer satisfaction}

Perceived quality can be explained as how customers view the services of a firm relative to other competing service offerings Perceived quality is, thus the perception held by customers and might not be the reality. Quality is explained by matching with the consumer's preferences (Parasuraman, Zeithamal, \& Berry, 1998). Perceived service quality has a critical role in the consumers' evaluation and decision-making process; thus, the perceived service quality is a critical concept in business and service marketing (Kim \& Han, 2008).

Service quality has been examined severally by a number of researchers, and, Lee, Lee, and Yoo (2000) noted that service managers should emphasize on the performance perceived by the customers rather than the difference between perceived performance and prior expectations. Hwang and Ok (2013) examined the interrelationships between three primary dimensions of service quality i.e. physical environment, interaction and outcome in casual and full-service restaurants (Clemes, Mohi, $\mathrm{Li}, \& \mathrm{Hu}, 2018$ ). Despite the importance of service quality, it is reported that, there is no conclusive evidence regarding which service quality dimension is important to consumer loyalty in the restaurant sector. However, in their study, Clemes et al. (2018) found service quality as one of the determinants of customer satisfaction in a restaurant setting. Also, Carranza, Díaz, and Martín-Consuegra (2018) report that several studies have found positive relationship between service quality and consumer satisfaction (Bufquin, DiPietro, \& Partlow, 2017; Wu \& Mohi, 2015). We propose therefore that:

H1: Perceived service quality is expected to have a positive effect on Customer satisfaction

H2: Perceived service quality is expected influence positively on Restaurant Image

H3: Perceived service quality is expected to have positive influence Perceived value of restaurant

\subsection{Perceived Value}

Perceived value as a concept has had an importance in marketing research for a long time (Chang \& Wang, 2010). Identifying customer needs and providing value for the customer has long been seen as a cornerstone of marketing and competitive strategy (Lindgreen \& Wynstra, 2005). Customer perceived value often has little to do with actual price. Instead, it deals with abstract costs. The perceived value is important because it determines the extent of willingness shown by the customers to purchase the product or service offered, such that, the greater the perceived value the greater the intent to purchase the product or service is shown by the customers (Dodds, Monroe, \& Grewal, 1991). Researchers agree that perceived value is a major influence on consumer loyalty (Fornell, Johnson, Anderson, Cha, \& Bryant, 1996; Oh, 2000; Yang \& Peterson, 2004).

Perceived value has been explained as "the benefits received relative to costs however, the construct may have a different meaning among individuals" (Clemes et al., 2018). Also, perceived value "may be a low price for some consumers, or the quality the consumer receives for the price they pay (Jang \& Jooyeon, 2015; Yüksel \& Yüksel, 2002) and the construct may positively influence customers' perceptions of service quality" (Gallarza \& Gil Saura, 2006; Hu, Kandampully, \& Juwaheer, 2009). Perceived value has been argued to have positive relationship with customer satisfaction (Chen, 2008). Therefore, the following hypotheses are proposed:

H4: Perceived value has a positive and direct effect on customer satisfaction 


\subsection{Restaurant image}

Brand image has been explained as "the sum of beliefs, ideas and impressions that a person or a group has of an object" which might be "a company, product, brand, place or person" (Clemes et al., 2018). Dobni and Zinkhan (1990) also defined brand image as "customer's emotional attitudes regarding a specific brand".Customers rely heavily on brand image in making purchasing decisions when they have little brand knowledge (Dodds et al., 1991). Brand image provides a product identity to customers. The image of a brand might be a determining factor in customer's brand evaluation and decision-making process of a choice of a restaurant. It might also serves as a guide for customers in assessing whether or not a restaurant can fulfil their needs (Eliwa, 2006). Restaurant image has been argued to positively influence both customer satisfaction (Eliwa, 2006; Ryu, Han, \& Kim, 2008) and behavioural intentions (Nguyen, 2006; Ryu, Han, \& Pearlman, 1989). As such, we propose these hypotheses that: H5. Restaurant image would positively influence consumers satisfaction

H6: Restaurant image is expected to have a positive influence of customer's behavioural intentions

\subsection{Customer Satisfaction and Behavioural intention}

Satisfaction has been thought of customer's evaluation of whether or not a product or service has met their expectations or not. Customer satisfaction is explained by the percentage of total customers or the total number of customers who reported that their experience with a firm, its products, or its services exceeds their specified satisfaction expectations. It is considered that customers judge products on a limited set of norms and attributes. Customer satisfaction has been defined to mean assessments made by customers with regards to product or service features that provides a positive result derived from consumption (Ali, 2016; Oliver, 2009). This concept has been examined in the restaurant sector to assess whether or not its outcome is dependent on service quality (Carranza et al., 2018)

High-standard customer service can win customers' hearts and make the product or service recognizable within a target group. In recent times, due to the proliferation of social media activities, it is important to keep an eye on a quality of customer service provided to consumers because consumer satisfaction can be an important marketing tool to companies' business growth. Hyun (2010) and Abdelhamied (2011) argue that positive perceptions of service quality has the tendency to elicit positive response from restaurant patrons and might engage in re-patronage and providing positive word-of-mouth. We therefore propose the hypothesis that:

H7: Customer Satisfaction is expected to have positive and direct influence behavioural intention of customers

The model structure of this paper is shown in Figure 1. The model shows the various relationships among the study's variables. It shows the direct relationship between the independent variable SQ and dependent variables Customer satisfaction, Perceived value, Restaurant image and Behavioural intention. There is also a direct relationship between the second order variables CS, RI and Behavioural intention. It also portrays the indirect relationships among the constructs.

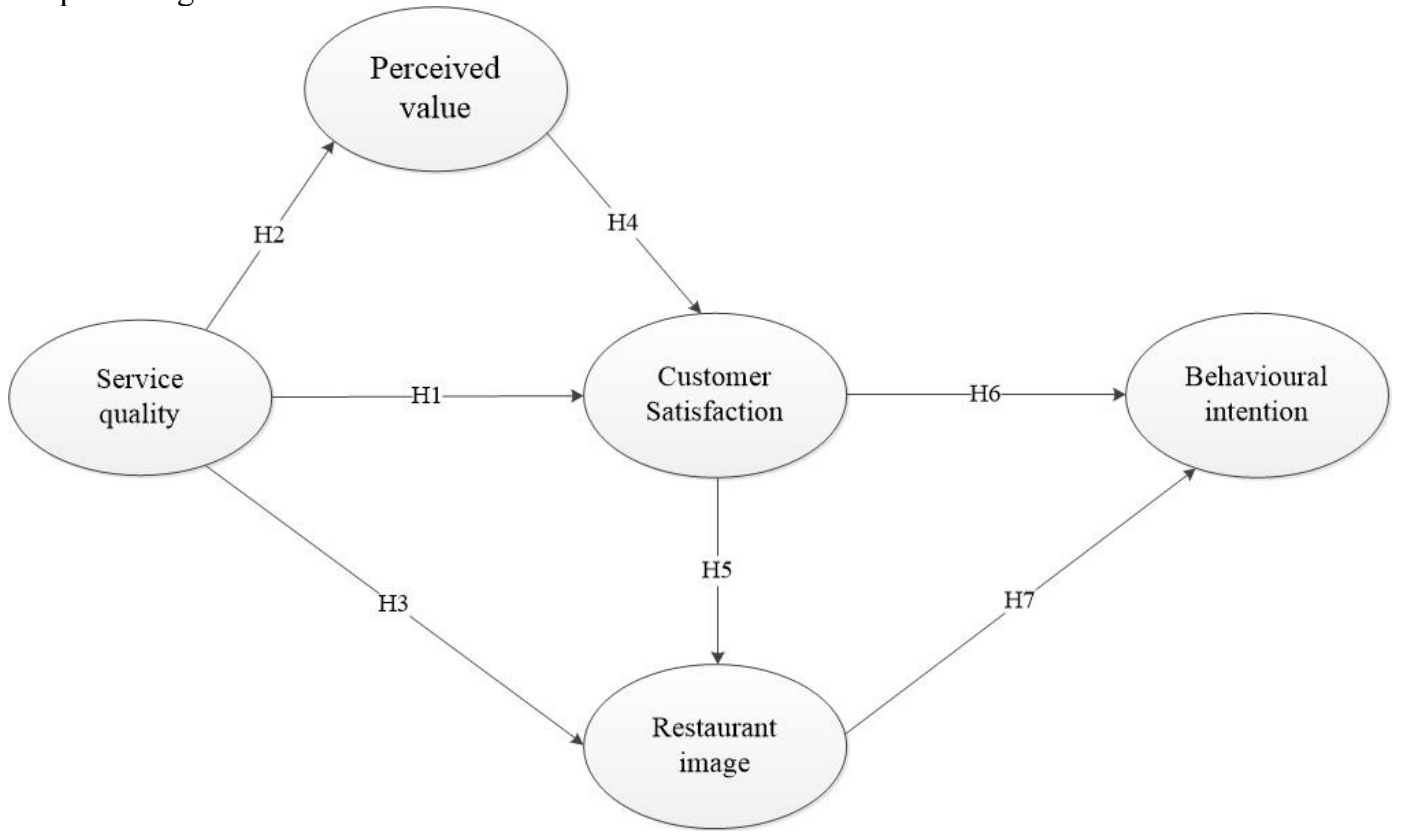

Figure 1.Conceptual model of the study

\subsection{Methodology}

The survey method was employed in this study to assess the effect of service quality on customers satisfaction and 
customer behavioural intentions in Chinese restaurants. The choice of the survey technique is based on its ability to accommodate large samples sizes and also due to its generalizability of results findings. The survey technique in this study is the self-administered technique which requires the author of the study to directly drop-off the surveys to the target restaurants.

This study considers the use of the Non-probability and convenience sampling because without a list of restaurant users it is not possible to identify the population of the study, nor estimate the sample size. To ensure that sample characteristics represents the population of the targeted restaurants' customers overall, attention is paid to the combined age of the people and their sex, the minimum age of attitude research is usually 18 .

Adopting a convenience sampling technique, the study sampled 329 restaurant customers in the Jiangsu province in China. A self-administered, structured questionnaire was developed, pre-tested and finally administered to the respondents through personal contact by researcher. The researchers used informed consent form to seek permission from the respondents and assured the respondents of anonymity and confidentiality of their responses.

A five-point Likert scale was used to measure variables for the research constructs as recommended in previous works. The Likert scale ranged from strongly disagree (1) to strongly agree (5). The items measuring the five multi-item constructs had 24 items that were adopted from previous studies and adapted to fit in our current study.

To analyse our study's findings, we first performed data cleaning and recording of the data to remove outliers through the Statistical Package for Social Sciences (SPSS V.22). Next, we performed an exploratory factor analysis (EFA) to determine number of factors to extract for our study using the direct varimax rotation. This enabled us to test the proposed relationships among the study variables. Drawing on the view of Pallant (2011), three main steps were followed in carrying out the EFA: "(1) Assessment of the suitability of the data for factor analysis, (2) Factor extraction, and (3) Factor rotation and interpretation."

After EFA, we also performed a confirmatory factor analysis (CFA) and then transferred the data SmartPLS 3 for further analysis. Our proposed model was, therefore, assessed for model fitness using the structural equation modeling (SEM) via SmartPLS 3.

\subsection{Results of the Study}

\subsection{Confirmatory Factor Analysis (CFA)}

Our study performed the Harmann's Single-Factor test to check the common method variance. This test was conducted using exploratory factor analysis (EFA) and loading 6 items on one factor. Twenty-six items were initially entered but 6 of the items were later removed leaving 20 items. The remaining items or components explained about $95 \%$ of the variance in our sample (see table 1 ).

Table 1. KMO and Bartlett's Test

Kaiser-Meyer-Olkin Measure of Sampling Adequacy.

Bartlett's Test of Sphericity
Approx. Chi-Square

Df

Sig.
.952

9278.068

820

.000

4.1.2 Reliability and validity of Scales

To check the reliability of our scales, we first tested for convergent and discriminant validity. Bartlett's Test of Sphericity was adopted for the measurement of construct validity whiles the Kaiser-Meyer-Olkin (KMO) was employed for the measurement of Sampling Adequacy of individual variables. To perform factor analysis, it is expected that the KMO overall score should be 0.6 or higher (Özdamar, 2017). Accordingly, the results of the Bartlett's test of Sphericity and KMO revealed that both are significant and suitable for the factor analysis (Table $1)$.

The result of the cumulative variance shows $95 \%$, which exceeds the minimum acceptance level of $60 \%$ (Özdamar, 2017), The Bartlett's Test of Sphericity from the table above shows that the correlation between the variables is 9278.068 which is sufficient, and significant $(\mathrm{P}>0.000)$. Whiles the factor loadings of all the construct exceeded 0.5 (Hair Jr, Sarstedt, Ringle, \& Gudergan, 2017; Ringle, Wende, \& Becker, 2015). The figures in the table shows that, there is convergent and discriminant validity (See Table 1).

4.1.3 Measurement model reliability and validity

To assess the internal consistency of our result, we tested the reliability of our constructs. We assessed this through the item factor loadings which exceeded 0.70 and also through the Cronbach's alpha which were all higher than the required level of 0.7 (Hair, Ringle, \& Sarstedt, 2011; Ringle et al., 2015). 
Table 2: Item loading and construct reliability

\begin{tabular}{|c|c|c|c|c|c|c|}
\hline & FL & $\mathrm{CA}$ & & $\mathrm{CR}$ & & \\
\hline BI1 & 0.845 & 0.910 & 0.911 & & 0.933 & 0.735 \\
\hline $\mathrm{BI} 2$ & 0.846 & & & & & \\
\hline $\mathrm{BI} 3$ & 0.877 & & & & & \\
\hline BI4 & 0.868 & & & & & \\
\hline BI5 & 0.850 & & & & & \\
\hline CSAT1 & 0.869 & 0.803 & 0.803 & & 0.871 & 0.629 \\
\hline CSAT2 & 0.904 & & & & & \\
\hline CSAT3 & 0.835 & & & & & \\
\hline CSAT4 & 0.791 & & & & & \\
\hline IM1 & 0.761 & 0.872 & 0.873 & & 0.913 & 0.724 \\
\hline IM2 & 0.820 & & & & & \\
\hline IM3 & 0.795 & & & & & \\
\hline IM4 & 0.794 & & & & & \\
\hline Pv1 & 0.807 & 0.746 & 0.761 & & 0.852 & 0.658 \\
\hline Pv2 & 0.842 & & & & & \\
\hline Pv3 & 0.783 & & & & & \\
\hline SQ1 & 0.845 & 0.846 & 0.853 & & 0.896 & 0.683 \\
\hline SQ2 & 0.816 & & & & & \\
\hline SQ3 & 0.807 & & & & & \\
\hline SQ4 & 0.837 & & & & & \\
\hline
\end{tabular}

Notes: FL - Item Loadings, BI - Behavioural intentions, CSAT - Customer satisfaction, IM - Image, Pv Perceived value, SQ - Service quality, AVE-Average variance extracted, CR- Composite reliability, CA Cronbach's alpha

Again, we also ensured convergent validity using the average variance extracted (Larsen, Attkisson, Hargreaves, \& Nguyen) and composite reliability (Brady et al.). From table 2 the convergent validity was also achieved since the AVE and CR satisfied the minimum requirement of 0.50 and 0.70 respectively (Fornell \& Larcker, 1981; Ringle et al., 2015)

Table 3. Discriminant Validity

\begin{tabular}{llllll}
\hline & BI & Bimage & CSAT & Pvalue & ServQuality \\
\hline BI & 0.857 & & & & \\
\hline Bimage & 0.431 & 0.793 & & & \\
\hline PSAT & 0.734 & 0.468 & 0.851 & & \\
\hline ServQuality & 0.432 & 0.577 & 0.571 & 0.811 & \\
\hline
\end{tabular}

The table 3 show the discriminant analysis which requires a factor to correlate higher than with any other construct on its scale (Messick, 1988). All the variables in the Table xxx loaded higher than any other factor on their scales. Behavioural intention had a value (0.85) which was higher than all the other values on that scale. Restaurant image had a value of (0.79), CSAT (0.85), Pvalue (0.8), and Service quality (0.8).

\subsection{Results of Structural Model}

We assessed the structural model using the regression weights, t-values, and p-values for significance of t-statistics (Chin, 2010; Ringle et al., 2015). The results of structural model for testing the research hypotheses are presented in Figure 2 and Table 4. 


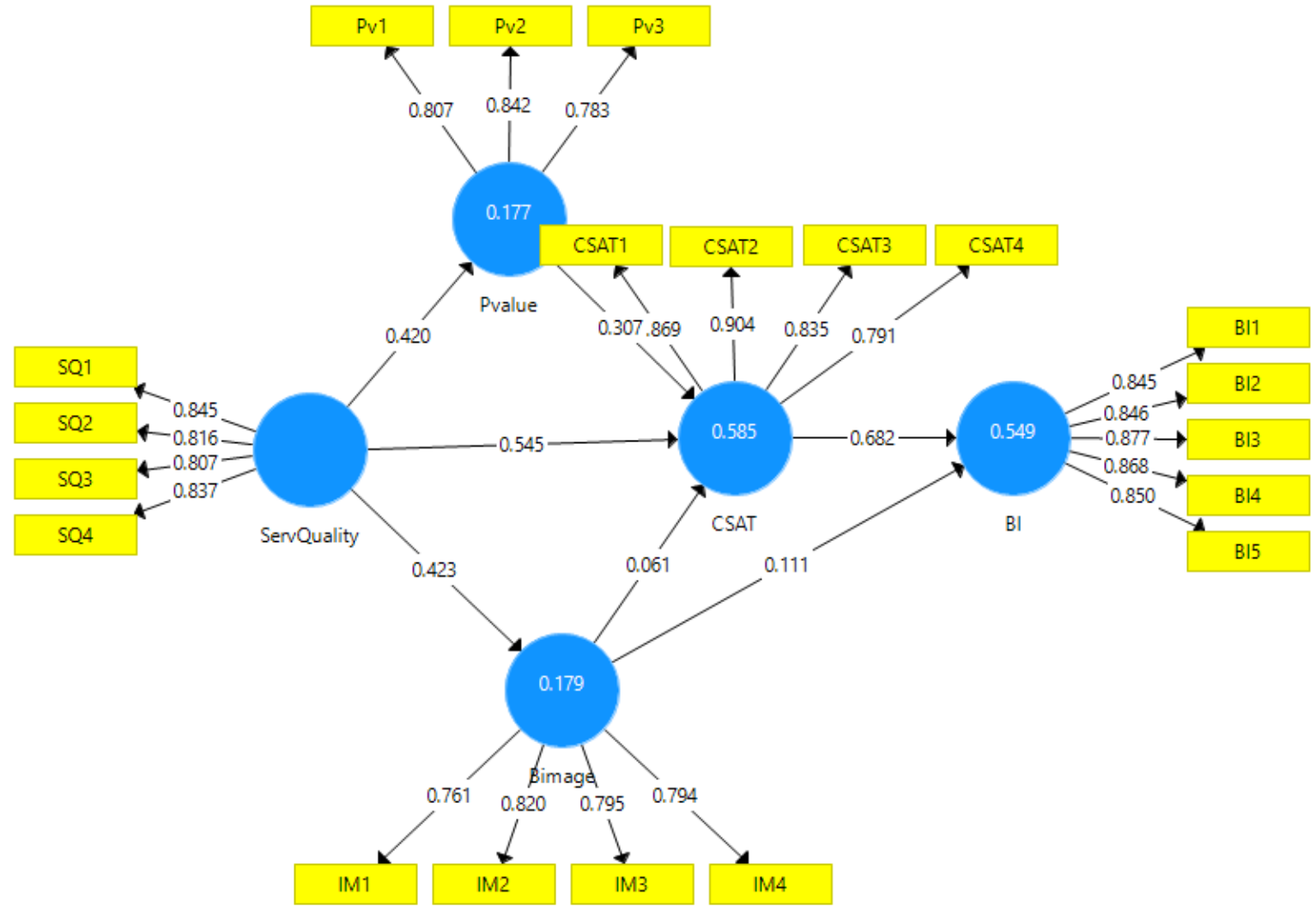

Figure 2. Structural model showing relationship among the variables

Figure 2 shows the structural model's assessment regarding the relationship between the variables. The assessment includes the path coefficients that estimate the relationship between the variables. From Figure 2, service quality related positively with perceived value and restaurant image $(0.420)$ and $(0.423)$ respectively. Also, perceived value and restaurant image both related positively with customer satisfaction 0.307 and 0.061 respectively. This means that image as well as perceived value shapes satisfaction of customers. Again, customer satisfaction and restaurant image both related positively with behavioural intention 0.0682 and 0.111 respectively. This also means that customer satisfaction and brand image influence behavioural intention of customers positively. 4.2.1 Hypothesis test

We tested the hypotheses using bootstrapping method with 5000 samples to assess the effect of service quality and customer satisfaction on consumers' behavioral intention in restaurant setting in China. Six out of the 7 hypotheses tested showed a positive and significant relationship among the hypothesized relationships (H1, H2, H3, H4, H6 and $\mathrm{H} 7 ; \mathrm{p}<0.05$ ). Service quality had a positive and significant relationship with CSAT, Pvalue and RI. This led to the acceptance of $\mathrm{H} 1, \mathrm{H} 2$ and $\mathrm{H} 3$ respectively. The first hypothesis shows a positive and significant relationship between SQ and CSAT $(\beta=0.545 ; \mathrm{t}=12.03 ; \mathrm{p}<0.001)$ and this led to the acceptance of H1. This means that would be satisfied with their restaurant service once they perceive quality of service from the service providers. The Beta score here means that when service quality improved by $1 \%$ customer satisfaction increases by about $54 \%$.

The second hypothesis $\mathrm{H} 2$ also shows a positive and significant effect of SQ on perceived value $(\beta=0.420$; $\mathrm{t}=8.19 ; \mathrm{p}<0.001)$ and this led to the acceptance of $\mathrm{H} 2$. This finding also means that, once customers perceive quality of service from the service providers, they place high value on the service provider which might influence their future intention of vising the same restaurant. Hypothesis 3 also found a positive and significant relationship between SQ and restaurant image ( $\beta=0.423 ; \mathrm{t}=7.54 ; \mathrm{p}<0.001)$; this led to the acceptance of H3. The Beta score here means that when service quality improves by $1 \%$, brand image of the restaurant also increases by about $42.3 \%$. In the second model, two hypotheses were tested $\mathrm{H} 4$ and $\mathrm{H} 5$. The fourth hypothesis also shows a positive and significant relationship between perceived value and customer satisfaction $(\beta=0.307 ; \mathrm{t}=6.98 ; \mathrm{p}<0.001)$; this led to the acceptance of hypothesis $\mathrm{H} 4$. This means that, perceived value of the restaurant would have a positive effect on the satisfaction customers receive from the service provider. However, the fifth hypothesis showed a positive but insignificant relationship between Image and Customer satisfaction $(\beta=0.061 ; t=0.99 ; p>0.05)$. Image of the restaurant although has a positive effect on the satisfaction of customers, the effect is however not significant. 


\begin{tabular}{lllll} 
Path & Beta & STDEV & t-value & p-value \\
\hline H1 ServQuality -> CSAT & 0.545 & 0.045 & 12.032 & 0.000 \\
H2 ServQuality -> Pvalue & 0.420 & 0.051 & 8.187 & 0.000 \\
H3 ServQuality -> Bimage & 0.423 & 0.056 & 7.541 & 0.000 \\
H4 Pvalue -> CSAT & 0.307 & 0.044 & 6.987 & 0.000 \\
H5 Bimage -> CSAT & 0.061 & 0.061 & 0.992 & 0.321 \\
H6 CSAT -> BI & 0.682 & 0.045 & 15.238 & 0.000 \\
H7 Bimage -> BI & 0.111 & 0.048 & 2.303 & 0.021
\end{tabular}

The third model also shows a positive and significant relationship between customer satisfaction, restaurant image and BI $(\mathrm{p}<0.05)$. hypothesis 6 showed a positive and significant relationship between customer satisfaction and behavioural intention $(\beta=0.682 ; \mathrm{t}=15.24 ; \mathrm{p}<0.001)$; this led to the acceptance of hypothesis H6. This finding means that, customer satisfaction has a strong influence on customer's intention to re-patronize a particular restaurant or service provider. The seventh hypothesis also had a positive and significant relationship with BI $((\beta$ $=0.111 ; \mathrm{t}=2.3 ; \mathrm{p}<0.05)$ and this led to the acceptance of hypothesis $\mathrm{H} 7$. This finding also means that customer's perception of brand image of the restaurant would influence their re-patronage behavior of their service provider (see Table 4). 7

Table 5. Indirect effect

\begin{tabular}{lcccccc}
\hline & Beta & Mean & SD & t-value & p-value \\
\hline ServQuality -> Bimage -> BI & 0.047 & 0.049 & 0.025 & 1.923 & 0.055 \\
ServQuality -> Bimage -> CSAT -> BI & 0.018 & 0.018 & 0.018 & 0.967 & 0.333 \\
ServQuality -> Pvalue -> CSAT -> BI & 0.088 & 0.088 & 0.017 & 5.331 & 0.000 \\
ServQuality -> CSAT -> BI & 0.372 & 0.37 & 0.048 & 7.787 & 0.000 \\
ServQuality -> Bimage -> CSAT & 0.026 & 0.027 & 0.027 & 0.954 & 0.340 \\
ServQuality -> Pvalue -> CSAT & 0.129 & 0.129 & 0.024 & 5.461 & 0.000
\end{tabular}

Aside the direct relationship with regards to the hypothesized relationships, we also tested the indirect relationships the endogenous variables had on the exogenous variables. Service quality influenced BI indirectly through four paths which were all positive. The first path ServQuality $->$ Bimage $->$ BI shows a positive and significant indirect effect between SQ and BI $(\beta=0.047 ; t=1.92 ; p<0.05)$. The second path, ServQuality $->$ Bimage $->$ CSAT $->$ BI shows a positive but insignificant indirect effect between SQ and BI $(\beta=0.047 ; t=1.92$; $\mathrm{p}<0.05)$. the third path ServQuality $->$ Pvalue $->$ CSAT $->$ BI also shows a positive and significant indirect effect between SQ and BI $(\beta=0.088 ; t=5.33 ; p<0.001)$. The fourth path ServQuality $->$ CSAT $\rightarrow$ BI also shows a positive and significant indirect effect between SQ and BI $(\beta=0.372 ; t=7.788 ; p<0.001)$.

Again, there was an indirect relationship established between SQ and CSAT in two different paths. The first path, ServQuality -> Bimage -> CSAT shows a positive and significant indirect effect between SQ and CSAT ( $\beta$ $=0.026 ; t=0.95 ; p<0.5)$. This finding means that that service quality influences CSAT indirectly through rand image and also through Perceived value. Thus, this finding further suggests that, brand image mediates the relationship between service quality and customer satisfaction. The second path, ServQuality $->$ Pvalue $->$ CSAT also shows a positive and significant indirect effect between SQ and CSAT $(\beta=0.129 ; \mathrm{t}=5.46 ; \mathrm{p}<0.001)$. The finding here also means that brand image mediates the relationship between service quality and customer satisfaction. Firms that want to ensure the satisfaction of customers must therefore also pay attention to the value they offer customers. Restaurant owners and service providers must ensure to provide value for money services for their customers at all times.

\section{Conclusion and Implication}

This study sought to assess the effect of service quality on customers satisfaction as well as the effect of customer satisfaction and restaurant image on the behavioural intention of restaurant patrons in China. The finding from this study suggest that, service quality greatly influence customer satisfaction directly and indirectly through perceived value and brand image. To ensure satisfaction of customers, restaurant owners and other service providers must pay particular attention to their brand image. Also, the patronage or re-patronage intention of restaurant customers depends largely on the quality of service, customer satisfaction and restaurant image.

Firms that need to carve niche for themselves in the hospitality industry must therefore focus on building a strong and positive brand image that resonates with customers. This is because, image of the brand sends a strong message to customers and potential customers about the kind of service they would receive from the service providers.

Again, care must be taken to provide better services to customers the first time to create first impression about the level of quality service delivery. When done, this might help the restaurant achieve customer satisfaction and 
build long-term profitable relationship with customers. Management should therefore ensure that they maintain good hygiene, neat and tidy eating space, well ventilated and environmentally friendly dining area. This would create a kind of place customers would feel safe and secure to dine at.

Author Contributions: All authors contributed equally to this work. All authors wrote, reviewed, and commented on the manuscript. All authors have read and approved the final manuscript.

Funding: This work was supported by the National Natural Science Foundation of China (Nos. 71971100,71671078,71501084,71974081,71771127);Social Science Fund of Jiangsu Province

(19GLB005,19GLB018; The Key Project of Philosophy and Social Science Research in Colleges and Universities in Jiangsu Province (2018SJZDI052); sponsored by Qing Lan Project of Jiangsu Province; Youth Backbone Teacher Training Project of Jiangsu University.

Acknowledgments: The authors would like to acknowledge the professionals who collaborated on this study. We would also like to thank all the reviewers who provided suggestions to improve this paper.

Conflicts of Interest: The authors declare no conflict of interest. The funders had no role in the design of the study; in the collection, analyses, or interpretation of data; in the writing of the manuscript, or in the decision to publish the results.

\section{References}

Abdelhamied, H. H. S. (2011). Customers' perceptions of floating restaurants in Egypt. . Anatolia: An International Journal of Tourism \& Hospitality Research, 22(1), 1-15.

Ahmed, J., Hossain, M. L., Malek, M. A., \& Begum, F. (2008). Assessment Bacteriological Quality of Fast Foods and Soft Drinks in Relation to Safety and Hygiene Bangladesh. Journal of Microbiology, 25(1), 73-75.

Akbar, Y. A. A., \& Alaudeen, M. S. S. (2012). Determinant of Factors that Influence Consumer in Choosing Normal Full-Service Restaurant: Case in Seri Iskandar, Perak, Malaysia. South East Asian Journal of Contemporary Business, Economics and Law, 2(1), 137-145.

Ali, F. (2016). Hotel website quality, perceived flow, customer satisfaction and purchase intention. Journal of Hospitality and Tourism Technology, 7(2), 213-228.

Brady, M. K., Cronin, J. J. J., \& Brand, R. R. (2002). Performance-only measurement of service quality: a replication and extension. Journal of Business Research, 55(1).

Bufquin, D., DiPietro, R., \& Partlow, C. (2017). The influence of the DinEX service quality dimensions on casualdining restaurant customers' satisfaction and behavioural intentions. Journal of Foodservice Business Research, 20(5), 542-556.

Carranza, R., Díaz, E., \& Martín-Consuegra, D. (2018). The influence of quality on satisfaction and customer loyalty with an importance-performance map analysis: Exploring the mediating role of trust. Journal of Hospitality and Tourism Technology, 9(3), 380-396.

Chang, H. H., \& Wang, H.-W. (2010). The moderating effect of customer perceived value on online shopping behavior. Online Information Review, 35(3), 333-359.

Chen, C. F. (2008). Investigating structural relationships between service quality, perceived value, satisfaction and behavioural intentions for air passengers: evidence from Taiwan. Transportation Research Part A: Policy \& Practice, 42(4), 709-717.

Chin, W. (2010). How to write up and report PLS analyses. In C. W. W. Esposito, V. Vinz, J. Henseler, \& H. Wang (Eds.), Handbook of partial least squares: concepts, methods and applications (pp. 655 - 690). Heidelberg: Springer.

Clemes, D. M., Mohi, Z., Li, X., \& Hu, B. (2018). Synthesizing moderate upscale restaurant patrons' dining experiences. Asia Pacific Journal of Marketing and Logistics, 30(3), 627-651.

Dobni, D., \& Zinkhan, G. M. (1990). In search of brand image: a foundation analysis. NA-Advances in Consumer Research, 17, 110-119.

Dodds, W. B., Monroe, K. B., \& Grewal, D. (1991). Effects of price, brand, and store information on buyers' product evaluations. Journal of Marketing Research, 28(3), 320-327. doi:10.2307/3172866

Eliwa, R. A. (2006). A study of customer loyalty and the image of the fine dining restaurant.

Farrell, D., Gersch, U. A., \& Stephenson, E. (2006). The value of China's emerging middle class. McKinsey Quarterly, 2(1), 60.

Fornell, C., Johnson, M. D., Anderson, E. W., Cha, J. S., \& Bryant, B. E. (1996). The American customer satisfaction index: nature, purpose, and findings. Journal of Marketing, 60(4), 7-18.

Fornell, C., \& Larcker, D. F. (1981). Evaluating structural equation models with unobservable variables and measurement error. Journal of Marketing Research, 18(1), 39-50.

Gallarza, M. G., \& Gil Saura, I. (2006). Value dimensions, perceived value, satisfaction and loyalty: an investigation of university students' travel behaviour. Tourism Management, 27(3), 437-452. 
Hair, J., Ringle, C. M., \& Sarstedt, M. (2011). PLS-SEM: Indeed, a Silver Bullet. Journal of Marketing Theory and Practice, 19(2), 139-151.

Hair Jr, J. F., Sarstedt, M., Ringle, C. M., \& Gudergan, S. P. (2017). Advanced issues in partial least squares structural equation modeling: Sage Publications.

Hu, H. H., Kandampully, J., \& Juwaheer, T. D. (2009). Relationships and impacts of service quality, perceived value, customer satisfaction and image: an empirical study. Service Industries Journal, 29(2), 111-125.

Hwang, J., \& Ok, C. (2013). The antecedents and consequence of consumer attitudes toward restaurant brands: a comparative study between casual and fine dining restaurants. International Journal of Hospitality Management, 32, 121-131.

Hyun, S. S. (2010). Predictors of relationship quality and loyalty in the chain restaurant industry. Cornell Hotel \& Restaurant Administration Quarterly, 51(2), 251-267.

Ibrahim, Y., \& Vignali, C. (2005). Predicting Consumer Patronage Behaviour in the Egyptian Fast Food Business Innovative Marketing. Journal of food sciences, 1(2), 60-76.

Jang, S., \& Jooyeon, H. (2015). The influence of cultural experience: emotions in relation to authenticity at ethnic restaurant. Journal of Foodservice Business Research, 18(3), 287-306.

Kim, W., \& Han, H. (2008). Determinants of Restaurant Customers' Loyalty Intentions: A Mediating Effect of Relationship Quality. Journal of Quality Assurance in Hospitality \& Tourism, 9(3), 218-239.

Larsen, D. L., Attkisson, C. C., Hargreaves, W. A., \& Nguyen, T. D. (1979). Assessment of client/patient satisfaction: Development of a general scale. Evaluation and Program Planning, 2(2), 197-207.

Lee, H., Lee, Y., \& Yoo, D. (2000). The determinants of perceived service quality and its relationship with satisfaction. Journal of Services Marketing, 14, 3.

Lindgreen, A., \& Wynstra, F. (2005). Value in business markets: what do we know? Where are we going? Industrial Marketing Management, 34(7), 732-748.

Ling, K. C., Mun, Y. W., \& Ling, H. M. (2011). Exploring Factors that Influence Customer Loyalty Among Generation Y for the Fast Food Industry in Malaysia. African Journal of Business Management, 5(12), 48134823.

Messick, S. (1988). Validity. In R. L. Linn (Ed.), Educational Measurement (3rd ed.). New York, NY: Macmillan.

Nguyen, N. (2006). The collective impact of service workers and servicescape on the corporate image formation. International Journal of Hospitality Management, 25(2), 227-244.

Oh, H. (2000). The effect of brand class, brand awareness, and price on customer value and behavioural intentions. Journal of Hospitality and Tourism Research, 24(2), 136-162.

Olise, M., Okoli, M., \& Ekeke, J. (2015). Factor influencing customers patronage of fast food restaurants. International journal of economic commerce and management, 3(11), 686-701.

Oliver, R. L. (2009). Whence consumers loyalty? Journals of marketing, 63(4), 33-44.

Özdamar, K. (2017). Ölçek ve test geliştirme yapısal eşittlik modellemesi IBM SPSS, IBM SPSS AMOS ve MINTAB uygulamal. [Scale and test development Structural equation modeling IBM SPSS, IBM SPSS AMOS and MINTAB applied]. Eskișehir: Nisan Kitabevi.

Parasuraman, A., Zeithamal, V. A., \& Berry, L. L. (1998). SERVQUA: A multiple-item scale for measuring consumer perceptions of service quality. Journal of Retailing, 64, 12-40.

Parasuraman, A., Zeithaml, V., \& Berry, L. (1988). SERVQUAL: A multi-item scale for measuring consumer perceptions of service quality. Journal of Retailing, 64, 12-40.

Park, C. (2004). Efficient or enjoyable? Consumer values of eating-out and fast restaurant consumption in Korea. International Journal of Hospitality Management(23), 87-94.

Ringle, C. M., Wende, S., \& Becker, J. M. (2015). SmartPLS 3. Hamburg: SmartPLS.

Ryu, K., Han, H., \& Kim, T. H. (2008). The relationships among overall quick-casual restaurant image, perceived value, customer satisfaction, and behavioral intentions. International Journal of Hospitality Management, 27(3), 459-469.

Ryu, K., Han, H., \& Pearlman, D. (1989). The relationships among store image, perceived value, customer satisfaction, and behavioral intentions in the fast-casual restaurant industry. International Journal of Contemporary Hospitality Management, 22(3), 416-432.

Tabassum, A., \& Rahman, T. (2012). Differences in consumer attitude towards selective fast food restaurants in Bangladesh: An implication of Multi attribute attitude model. World review of Business Research, 2(3), 1227.

Tat, H. H., Sook-Min, S., Ai-Chin, T., Rasli, A., \& Hamid, A. B. A. (2011). Consumers' Purchase Intentions in Fast Food Restaurants: An Empirical Study on Undergraduate Students. The Special Issue on Contemporary Issues in Business and Economics, 2(5), 214-221.

Wu, H. C., \& Mohi, Z. (2015). Assessment of service quality in the fast-food restaurant. Journal of Foodservice Business Research, 18(4), 358-388.

Yang, Z., \& Peterson, R. T. (2004). Customer perceived value, satisfaction, and loyalty: The role of switching costs. 
Psychology and Marketing, 21(10), 799-822.

Yüksel, A., \& Yüksel, F. (2002). Measurement of tourist satisfaction with restaurant services: a segment-based approach. Journal of Vacation Marketing, 9(1), 52-68. 